\title{
NAFTA's Impact on Korean Exports
}

\author{
KYE WOO LEE*
}

Many Asian countries are onncerned that as the negrotiations for the propusat Free Track Agreenent of the Americas (FTAA) are concluded in 2005, it may erode their share of the largest trading market, North America. As a tirst step toward assessing the impact of the FIAA on Asian countries, this paper evaluates the effects of FTAA's predecessur, the Norch Anerician Free Trade Agreement (NAFTA), on Korean external trade. Anzalyes of the shift in shares, trade intensity indices, and gravity models are used to assess the impact at a macro lenel, while trade diversion and creation effects are tested at sub-industry levels. Some lessons for future action are also drawn.

Keyurerds: Free Trade, NAFTA, Nurch Ancrica, East Asia, Korea, preferencial rrading arrangement, trade diversion, rrade creation

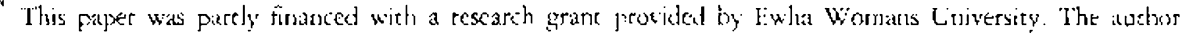

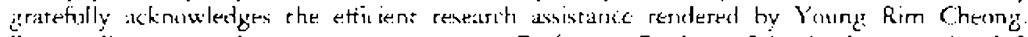
Direct all contespondence os Kye Won Lec, Protessur, Graduate School of International Studies. Ewha

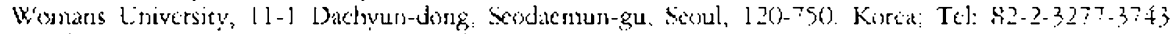

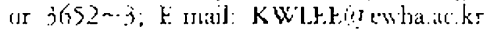




\section{INTRODLCTION}

A

t the beginning of 2003 , all Latin American democracies reconfirmed that negotiations for free Trade Arreement of the Americas (F'IAA) are to be concluded by 2005. This announcement caused consternation in many Asian countries, particularly Kurea. The inpact of FiAAs on Asian economies is potentially detrimertal beciuse the agrecmene would life non-tariff barriers among mernbers and accord preferential tariffs to 3.4 Western Hemispheric countrics with 800 million perple, the major export markets of Asian cconornics.

Justification for such a fear, however, is debatable. The historical predecessor $t o$ FlAA. NAlla of 199.1, was conduded beeween Canada, Mexico, and the Inited Statcs. While this alarmed Asian couneries at the time. NAFTA members' share of world exports only increased from $17.6 \%$ in 199.3 to $18.9 \%$ in 1999.

Scholars are divided as to the effects of preferential trade agrecments (PTAs), such as the FTAS and VAFTA. Some economises argue that, on hatatire, they lead to lower trate barrices among members without raising hacriers to nun-members, as is required by Article xxiv of the General Agreement on Tariffis and Trade (CATT). lior ceitrnple, Bergsten (19)6) arguks that I'lAs are building blocks tor trade liberalization on at global scale. Others, such as Bhagwati (1991), oppose discriminatory regional and sther preferential trating arrangemenes on the grounds that they undermine the guicting princigles of (IATT and the Workd Trade Organization (W'TO), namely world weltate and multilateralism.

As Vuncr (B)50) nutes, PTAs may contrance or redure world welfare depending on the magnirude of trade creation and diversion. Therefore, the net effect of PTAs on the wetlate of their memter countrics and on thisd party countries can be studied enpirically.

Trade creation within a PTA is the process by which countrics lowering their tariftes shift from reliance on high-cost domestic industry to imports from low cose partner counerica. Trade diversion acurs when lower-cost production in the rest of the world is displaced loy lighther-cost prostuction is at partucer country

Athough chere bave treen several studies on the impact of NAFlA on its members (e.g. Givded 1998, Kruger 1999 and 2000\%. Burfisher. Roshinsen, and Thierfekder 2001, Arnde and Huemer 2001 and 2002, and Fukao. Okubo, and Stem 2002?, and the Workd Bank 2001), there have been few comprehensive ex-post compirical studics on the impacts of NAFTh on Fast Astan economies, particularly on Kurea. The feet studies that do exist neither cover all sectors of an Last Astan economy, nor traide vis-ii-wis the whole world, bue focus only on selected labor-intensive sectors and trakte with . VAFT mernbers. livers if some studies cover world trade, they fail to identify whether the trade diversion excurred at the cxpense of Fast Asian countrics, particulisly Korcial.

Kreinin and Plummer (1998) only predicted that NAFIA is likcly to cause major

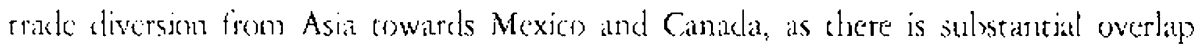


between these countries' comnodicy expors. Karemara and Ojah (1998) compare impacts on trade for selected manufacturers of ASEAN mombers and NAFTA using at gravity model, but they do nor caprure the effect of the post-effectiveness of the NAYTA, as their data end in 19\%?.

James and Limemoto (20x)(0) studied texriles and apparel sectors, which have restrictive rales of origin, coupled with large discriminatory trade preterences. They verify that trade diversion in the two sectors toraled $\$ 1.9$ billion in $1994, \$ 7.3$ billion in 1995 and $\$ 9.8$ billion in $19 \% 6$ (in constan 1990 prices). A control group analysis of footwear and electrical machinery supplements their work. James and Lmemoto suspect that. VAFTA has nee posirive effects on Last Asian trade, since trade in electrical machinery appears to be significantly liberalized and is much larger than trade in textiles, apparel. and fortwear. However, they remain silent in the analysis of other sectors.

Kruger, using changes in the paterns of trade flow's and gravity equations, noted that trade relationships innong NAFlA members intensified considerably, but did not find much evidence thist imports from the rest of the world decliuted as intra-NAFTA trade increased. She also found that WAFTA did not change cariff differcorials for U.S. imports from Mexico and East Asia drastically to cause any significant trade diversion.

Sloaga and Winters (2001) and Wall (2002) attempted more comprehensive studies of NAFTA, using a gravity-model approach. While Sloaga and Winters tound no cwidence of tracte diversion from NAFTA, Wall teund that total Japarese exports and imports were 5.4 percent and 9.2 perent lower, respectively.

Burfisher, Robinsorn, and Thiericlder (2001) provide a comprethensive survey of NAI'TA's inpace on the L:S. However, they point out the fallacies regarding mukh of the mactoeconomic discussion related to NAl"TA, such as bilateral trade balance with NAFTA mombers, and foxus on the sectoral adjusenomes in agriculnurc, antomotaile sectors, as well as textiks and apparel sectors. They addeess the trade diversion issue only with respect to texciles and appard, especially vis-à-vis Edst Asia, couforming James and Jmemuto's findiogs as nused above.

And and $\mathrm{Huemet}(2)(3)$ and 200?) show that Mexico increased its share of L.S imports of automobiles, celevision sers, textiles, and apparet at the expense of East Asian countries (China, Japun. Korca, and 'I'tiwan), through graphicial analyses and focus on selected trade secturs.

Fukar), Okuto, and Stern (20)(3)) fexus on a disaggrcgated kevel for selected lahor-intensive manufactured goods; using a version of the gravity model to identify the presence of trate diversion as a consequence of NAFTA. They cuticlude that Mexico's share of U.S. imports of labut-intensive goods, such as textiles and apparel, was siynificantly associated with the changes in tariff rates as a resule of NAFTA. But the study cannot directly show the locus of the rade diversion.

The purpose of this stixdy is to provide a compreherisive analysis of NAHTA's impace on Korean trade worletwite. This study will focus on the following issues:

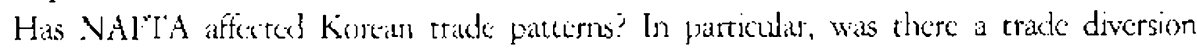


from Korca to NAFTA member councries? If yes, has the diversion taken place across all sectors of the economy, or has it been in proportion to the magnitude of rariff preference given to different sectors of NAFTA economies? Or was the diversion consistent with comparative advantare (or international competiciveness) of Korean exports?

This paper is divided into 7 sections. The sccond section makes an analysis of the shift in U.S.' share of Korean exports at the aggregate level. The third secrion applies the trade intensity index, i.c. U.S.'s share of Korean exports at the aggregate levcl, caking into account changes in the relative importance of the U.S. import market in the world import market. The fourth section deals with the yutestion of whether shifts in shares are consistent with tariff preferences accorded to different sectors of NAFTA economies, or with elfeiency and true comparative advantage of Korean cxports at sub-industry levels. The fifth section extends the comparative static analysis made in the previous section to an antalysis using continuous annual obserations and dynamic changes in the U.S. import markets vis-a-vis world import markets. The sixth section uses a form of gravity moxdels to invesrigate the causes of the changes in Korcar exports to the L.S. and other major export markets worldwite. The final section summarizes the findings of the study and draws some lessons and policy implicarions.

\section{ANALYSIS OF SHIFTS IN SHARE AT THE NATIONAI I.FVEL}

With the advent of NAFTA, Koreats toral exports increased stcadily from $\$ 26$ billion in 199. fo a 145 billion to 1999, and Korea s exports to NAFTA members incraased from $\$ 22.2$ billion to $\$ 32.3$ billion (Table 1). During the sanc priod, however. NAF'lA's share of Korcan exports (i.e. the proportion of Korean exports directed to NAFTA markers) derlined from 24\% co 23\% (Table 2). 'The U.S.' share of Korcan exports declined form 21.4\% in 1954 ro $15.8 \%$ in 1997 , and rebounded to 20.4\% in 1999. Mexico's and Canada's share of Korean exports remaned more wr less stahk: Korea's stare of NAFTA's toral import markees also declined from $2.5 \%$ in 1994 to $2.3 \%$ in 1948, rebounding to $2.6 \%$ only in 1999 (Table 3).

On the other hand, the proportion of NAFTA members total imports that cance frum other NAlTA members increased sharply from $3 ? .4 \%$ in 1994 to $40.3 \%$ in 1999. While the proportion of NAFTA's total imports that came from carada (i.t. Canadian exporse' share of total imports of NAFTA members) remained sable, and the proportion of . NAFTA's inports that came from the Ij.S. increased slightly, the share of NAFTA's rotal impurts that came from Mexico (i.e. the share of Mexico's exports ite the total impurts of NAl'TA members) rose sharply from $5.8 \%$ in 1994 to $8.2 \%$ in 1940 (lable 3). Therefore, one is likely to conclude that NAFTA bad negative effects on Korea's exports, and that there was at trade diversion from Korea to Mexicu from a Li.S. imports perspective. 
TAmif 1. KOREAS ExpokTs BY DesLINATION, 1988-1999

ILINIT: U.S. \& MJNI

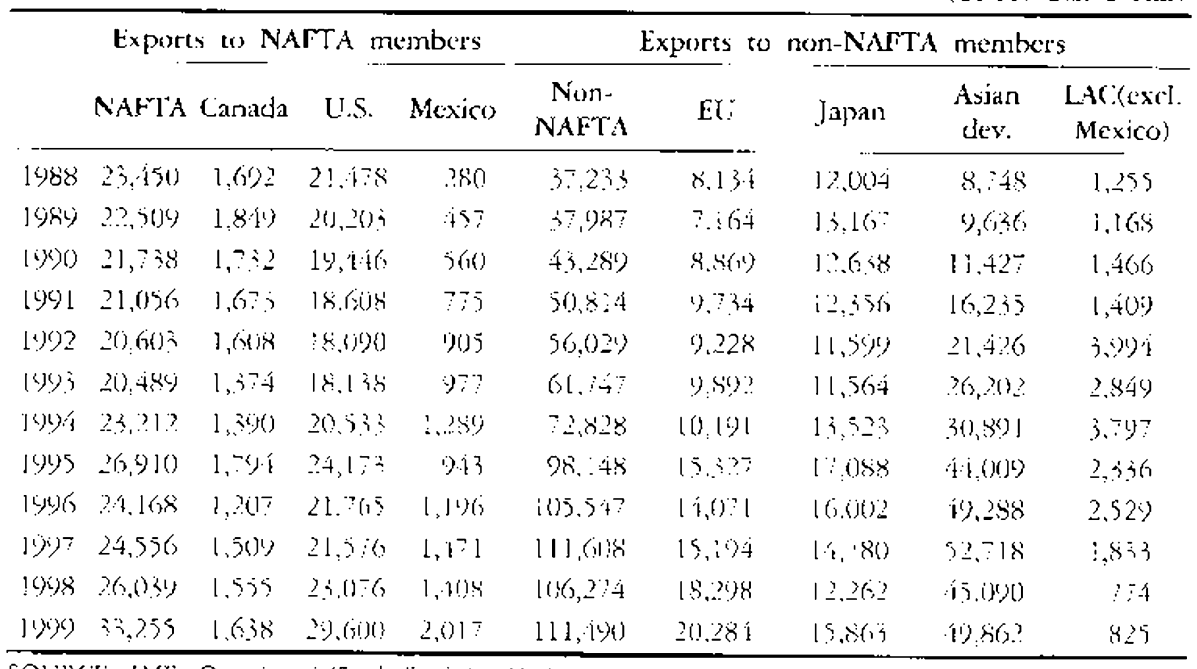

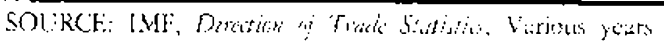

However, this is ton cautck a conclusion. Korean exports to NAFTA matrets in both absolute amounes and market share trikl besen steadily declining even before NAFTA touk ctfect in 199. NAFIA's share of Korean exports declinel from $38.6 \%$ (\$23.2 billion) in 1948 to 2.19\% (\$20.5 billion) in 1993 (Table 2). By country, L.S. and Canala set the trend. Only Mexicris share of Korcan exports increased from $0.5 \%$ in 1988 to $1.2 \%$ in 1993 . Korea's share of NAITA's total unport markets also declined from $10 \%$ in 1948 (0) $2.3 \%$ in 1993 (Table 3 ).

TABLE 2. DMIRJBITION OF KORETS EXPORTS HY DESTINATION, 1988-1999

(INNIT: PFR (ENT)

\begin{tabular}{|c|c|c|c|c|c|c|c|c|c|c|}
\hline \multirow{2}{*}{ ( } & \multirow{2}{*}{$\begin{array}{c}\text { Totid } \\
\text { Exputs } \\
\text { (LI.S.5 mus) }\end{array}$} & \multicolumn{4}{|c|}{ Expurts a YAHIA mombers } & \multicolumn{5}{|c|}{ Expotes a non-NAFHA members } \\
\hline & & NAFTA & Canada & I:.s. & Nexicon & $\begin{array}{l}\text { Non- } \\
\text { NAl'LA }\end{array}$ & ELi & Japan & $\begin{array}{l}\text { Asian } \\
\text { der. }\end{array}$ & $\begin{array}{c}\mathrm{I} A C(\mathrm{excl}) \\
\text { Mexicu) }\end{array}$ \\
\hline (1) 88 & $60.6 \times 5$ & 1 & 2.9 & 45.1 & 0.5 & 51.36 & 13.4 & $1 \% .8$ & $1 \dot{t} . j$ & 21 \\
\hline (istis & 60.396 & $5 \overline{2} \cdot 1$ & 3.1 & 3.1 & 0.4 & $(12,2)$ & $11 . x$ & $\therefore 1.8$ & 15.9 & 19 \\
\hline Iyst & 65,1827 & 23.43 & $2 ?$ & ?.). !) & 0.9 & $66.5 ?$ & 136 & 19.4́ & $: 7.6$ & 23 \\
\hline 19\%1 & 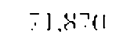 & 30.31 & 2.3 & 25.9 & $1 . !$ & 70.70 & $: 3.5$ & $1 ? \ldots$ & 22.6 & 20 \\
\hline $19 \%=$ & T\{, & $2(1)(0)$ & $\therefore 1$ & $\therefore\{6$ & $\therefore 2$ & $\bar{z}$. 11 & 12.9 & 15.1 & 280 & 5.2 \\
\hline $100 ?$ & $82=36$ & 2ध1.91 & 1.7 & 22.1 & 1.2 & $? 5.09$ & 1. is & $\mathrm{L}+\mathrm{i}$ & 31.9 & 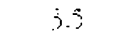 \\
\hline $1 y+1$ & )(一: (1) & $2 \cdot 1.1=$ & 1.1 & 21.1 & $1 . ?$ & 75.83 & 106 & l'́l. & $3 \geq .2$ & i.i) \\
\hline$!(x)=$ & $125.05 x$ & $31.5 ?$ & 1.4 & $1 y ;$ & 11.8 & $7 x$ & 13.3 & 1.7 & 35.2 & $1.1)$ \\
\hline $2 i 306$ & $120 ? \div 5$ & 18.63 & (3) & ] $6: 4$ & 11.9 & Ri. $3 ?$ & 110.8 & 123 & 3.8 .11 & 1.9 \\
\hline $\mid i k) ?$ & $136,1<1$ & 18.13 & 1.1 & 15.8 & 1.1 & $(31.97$ & 11.2 & 10.9 & $38 .=$ & 1.3 \\
\hline 1498 & $1,3,313$ & 19.69 & $1 \ldots$ & $17 . ;$ & 1.1 & 80.32 & 13.8 & 13.3 & 3.1 & i) 6 \\
\hline $19(\%)$ & 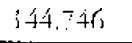 & 22.17 & 1.1 & $\geq 0.4$ & 1.4 & 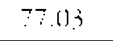 & 1 if & 11.0 & 3.1 .1 & 0.6 \\
\hline
\end{tabular}

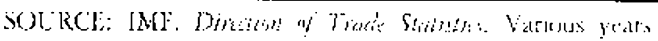


TABLE 3. DistribUtion OF NAFTA's IMPORTS by ORIGIN, 1988-1999

\{L INIT: PER CLNI\}

\begin{tabular}{|c|c|c|c|c|c|c|c|c|c|c|}
\hline \multirow[b]{3}{*}{$198 \mathrm{~s}$} & \multicolumn{4}{|c|}{ Imports from NAFTA members } & \multicolumn{6}{|c|}{ Imports from non-NAFTA members } \\
\hline & \multicolumn{2}{|c|}{ NAFTA Canada } & \multirow{2}{*}{$\begin{array}{l}\text { UU.S. } \\
1,2.2\end{array}$} & \multirow{2}{*}{$\frac{\text { Mexicb }}{4.2}$} & \multirow{2}{*}{$\begin{array}{l}\text { Non- } \\
\text { NAFTA } \\
6 ?:\end{array}$} & \multirow{2}{*}{$\begin{array}{l}\text { EU! } \\
15.8\end{array}$} & \multirow{2}{*}{$\frac{\text { Korea }}{4.0}$} & \multirow{2}{*}{$\frac{\text { Japan }}{17.3}$} & \multirow{2}{*}{$\begin{array}{l}\text { Asian } \\
\text { der. } \\
3.4\end{array}$} & \multirow{2}{*}{$\begin{array}{c}\text { LAC(cxal. } \\
\text { Mexico })\end{array}$} \\
\hline & $\because 2.3$ & 1.3 .9 & & & & & & & & \\
\hline 1989 & 330 & 1.2 & $1 \div 2$ & 4.6 & $6 ? 0$ & lki.i & 3.6 & $16:$ & 13.7 & 5.8 \\
\hline 190 & 3.3 & 14.1 & 14.3 & (1.) & 66.7 & 17.8 & 3.2 & 15.1 & 13.7 & 6.1 \\
\hline 1991 & 34.1 & 14.2 & $1+9$ & 5.1 & 63.8 & 18.5 & 2.9 & 15.8 & $1.4 ?$ & 5.7 \\
\hline 1943 & 35.7 & 13.8 & 16.7 & 5.2 & 64.3 & $16 \%$ & 2.7 & 15.0 & 15.3 & 5.5 \\
\hline 1203: & $3 x$ & l't...i & 16.4 & 1.: & $6 ? 2$ & 14.8 & 2.2 & $15 . \%$ & 163 & 90 \\
\hline$(y) \cdot 1$ & $\therefore i .4$ & 14.5 & 17.0 & 5.8 & 62.6 & 13.5 & 2.5 & 11.6 & 16.9 & 5.1 \\
\hline |yij & $3 i:$ & (1.4.) & 16.2 & 6.6 & $6 \% 3$ & 16.0 & 2.8 & 139 & $1 \% .8$ & 5.0 \\
\hline ארא & 39.2 & 15.0 & 16.9 & $? .3$ & 60.8 & 160 & 2.5 & 120 & 17.7 & 5.3 \\
\hline $19 y ?$ & .3) & $1+1 . \dot{t}$ & 12.8 & $? .3$ & 60.2 & 16.0 & $\therefore 3$ & 11.4 & 17.9 & 5.3 \\
\hline 1995 & 40.2 & $1 \therefore 2$ & 18.0 & 8.0 & 59.8 & 869 & 2.3 & 11.0 & $18 \%$ & 1.8 \\
\hline 149.0 & 40.3 & 14.4 & 17.7 & 8.2 & $39:$ & 10.7 & 26 & 106 & 18.1 & 4.9 \\
\hline
\end{tabular}

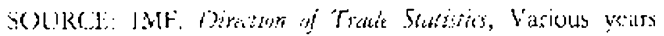

However, the analysis of shilts in share has a limited value. It does not solate DAFTA's cffexts from many other factors that affoced Korca's exports by destination. Moreover, the decline in NAF'PA's share of Korean exports had begun long before NAFIA rook effect. It could be prissible that NAFTA simply reinforced the dedining rencl of the . NAFTA's share of Korcan exports since 199. The same thing can be said ahout the Korean exports' share of NAFTA's total imports.

\section{TRADE INTENSITY ANAISYSIS AT THE NATIONAL JEVEL}

The above analysis of shifts in share assumes that NAFIA's importance in the work import matket is constant. However, this assumption necds to be checked against the changes in the inportance of NAFTA markets regarding total world imports. If this importance increases, the decline in NAFTA's share of Korcan exports would have more serious economic effects on the Korean economy. Conversely, if this importance declines shaply, the negative commic effects of the dedine on Korean exports could be roore than offset.

To take into account the possible changes in the importance of NAFTA markets in the work's etal impors, trade inrensity indices have bern computed for the period between 1988 and 1999, following the tradition of Brown (1947), Kojima (1961), Drysdale and Gatmatut (1982), Anderson (1983), and Yeats (1998). The intensity of trade index $\left(I_{11}\right)$ is defined as the proportion of country is total exports going to country $i\left(\mathrm{x}_{i} \mathrm{X}_{1}\right)$ relative to the share of is total imports $\left(\mathrm{M}_{i}\right)$ in world imports $\left(\mathrm{M}_{\mathrm{w}}\right)$. The equation is as follows: 


$$
l_{i:}=\left(\mathrm{x}_{\mathrm{i}} / \mathrm{X}_{\mathrm{i}}\right) /\left(\mathrm{M}_{\mathrm{i}} / \mathrm{M}_{\ldots}\right)
$$

If the bilateral trade intensity index is greater than wnity, the countries have greder bilateral trate than would be expected hased on the partuer's share in world trade. The rade inesonsty indeces for Korea with respece to individual and aggregared NAF" TA member countries are reported for the entire observation period of 1988-1999) (Table 4). The indices document the decreasing intensity of Korea's bilateral rade with NAFTA members. The bilateral trade intensity index for Korea's exports to the U.S. declined by half, from 2.18 to 1.13 over the whole period, and there wats

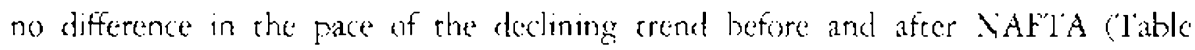
4). Intensity indices of trakts: with Cinadar declined from 0.72 or 0.31 . The indices for trade with Mexico increased brictly before NAlTA from 0.67 to 1.02 during the period $1988-1991$ and then gradually declined to $(0.72$ in 1992, continuing to 0.57 in 1999 in the post. NAFTA era. The intensiry indices for Korea vis-i-vis all VAFTA countries as a whole declined from 1.86 in 1988 to 1.17 in 1993, and further declined to 0.84 in $19 \%$ : before rising again to 0.95 in $14 \%$. The fact that the indices declined to a level less than unity means that the shatre of Korean exports directed to NAYTA countries was less than the importinnce ot the NAF'A's imports in world impors. The picture presented is not that differen from the shits in shares of trade as seen before (Table 2). This is due eis the more or less similar groweth

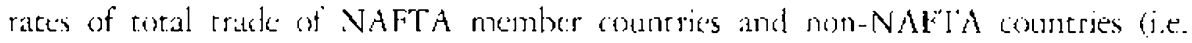
the anportance of NAFIA momber countrics in world trade has not changed much durings the observed peried).

TABLE 4. TRADI: INILASITY INISLX HOR KomLR, $1988-1999$

\begin{tabular}{|c|c|c|c|c|c|c|c|c|c|}
\hline & \multicolumn{4}{|c|}{ Trade wirh NAFTA menters } & \multicolumn{5}{|c|}{ Thoule with non-VAFIA members } \\
\hline & NAFIA & Canada & I..s. & Mexico & $\begin{array}{l}\text { Norr- } \\
\text { NAFtiA }\end{array}$ & E. & Japan & $\begin{array}{l}\text { Asjan } \\
\text { dev. }\end{array}$ & $\begin{array}{l}\text { IAC(r)ed } \\
\text { Mexico) }\end{array}$ \\
\hline $19 \times 5$ & 1.86 & 13.?? & $? 18$ & (i) 6 & (i) & 0.35 & $2.9 \%$ & 1.13 & 0.81 \\
\hline 1489 & I.j' & $13.84\}$ & $\therefore 19 x$ & $1.0 ?$ & i).71) & 0.51 & i.19 & $1.1 \%$ & $0 .: 8$ \\
\hline 1999 & 1.78 & $0.2 \mathrm{in}$ & $\therefore(1) ?$ & 1.00 & $(1,8)$ & 031 & 2.89 & 1.3 & 0.95 \\
\hline $1: 2 x 1$ & 1.58 & 1;.:16 & 1.83 & $1.0 ?$ & ii. $x:$ & (i.3) & 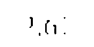 & 1.52 & 10.75 \\
\hline 1199. & 1.40 & 11.65 & $1.6 \mathrm{j}$ & $0 . \therefore$ & 0.91 & 0 (i & $\therefore .50$ & $1 \because:$ & 2.11 \\
\hline 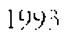 & $1.1:$ & 1). j6: & 1.36 & 1). (is & $(199)$ & 0.5 & $\therefore .1 .4$ & 1.75 & I.0si \\
\hline $1: y 44$ & 1.15 & $\{1 .-i\}$ & $1.3: \mathrm{j}$ & $0 . \therefore$ & 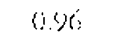 & $i \vdots \vdots 1$ & $\therefore 32$ & 1.73 & 1.22 \\
\hline 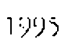 & 1.10 & $\{1 .-1\rangle$ & $1 . x$ & $0.5 \div$ & 0.98 & $0,3 j$ & $?(6)$ & 182 & 0.53 \\
\hline 1396 & 0.43 & (1).3y & 1.10) & 0.59 & 1.62 & (2).31 & 1.iju & 1.97 & 0.5? \\
\hline ly9: & 0.81 & $\{1 . \bar{z} 2$ & 0.09 & 0.55 & 1.01 & (0.0.7) & נ.s' & 2.116 & \{]$, i\}$ \\
\hline $13 y 8$ & $0.8:$ & $0.3 i$ & 利 & 0.1 .4 & $10 \%$ & (1). 2 . & 1.66 & $2.1 \%$ & IJitk \\
\hline ניקיגי & 0.05 & ii. $3:$ & $\therefore: 3$ & $0.5 \%$ & 1.02 & (1.3. & 2.91 & $2.0 ;$ & $1 \mathrm{~J} .16$ \\
\hline
\end{tabular}

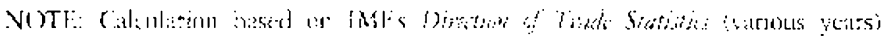

lirom the andysis of the shife in shares and the rrade intensity index, it is observed that Korean exports and the proporten of Korean exports diectod to NAPTA countrics 
steadily declined thefore and after NAFTA, and the pace of the decline did not accelcrate after NAFTA. Therefore, one cannot say that. NAFTA has had negarive effects on Korea's exports to NAFTA members, and that there was a trade diversion between L.S. imports from Kurea and Mexico.

While NAFl'A's strare of Korea's exports declined steadily, as we have scen in the above analysis, the non-NAFTA share of Korean exports increased gradually from $61.4 \%$ (\$37.2 billinn) in 1988 to $75.1 \%$ (\$61.8 billions in 1993 and to $77.0 \%$ (\$111.5 billion) in 1999 (Table 2).

Trade intensity indices for Korean expores also document the same trend. The indices for bilateral trade with non-NAFTA countrics steadily incrensed from 0.77 in 1988 to 0.95 in 1993, and then to 1.02 in 1999 ("Table 4). On the one hand, the intensity index for Koretn exports going to Latin American and Caribbean countries, excluding Mexico, stcadily declined from 0.81 in 1988 to 0.16 in 1999 . On the other hand the intensity index for Kurcan exports going to East Astian developing countries almost doubled from 1.13 in 1988 to 2.07 in 1999.

since the amount of Korcan exports to ROW countries is relatively larger than the arnourt of Korean exports to NAFTA members (Table I), the decline in NAFTA's intensiry is more than offset by the increase in non-NAFTA's intensity of Korean exports. Korean exports to NAFTA conntries decreased in absolute amounts, from $\$ 23.4$ billion in 1988 to $\$ 20.4$ billion in 1993 , hut increased to $\$ 33.2$ billion in 1999 an increasc of $\$ 9.8$ billion. However, Korea's exports to non-NAFl'A countries increased from $\$ 37.2$ billion in 1988 to $\$ 111.4$ billion in 1999, an increase of $\$ 74.2$ billion. Thercfore, any losses in Korcan exports to NAFl'A markets during this period were more than offset by expore increases to nom-NAFTA markets. The mer increase in Kurean exports worldwide between 1988 and 1999 was $\$ 50.8$ billion.

\section{TRADE IOIVERSION OR CREATION AT INDLSTRY LEVELS}

the above antlysis raises fundamental questions: Did the decline in shares and tride intersity indices take place in all industries unuformly, or was there any difference onnong induseres? Was the decline in shares and intensity indices by industry consistent with efficiency and true comparative advantage of Korean exports?

Io answer these cuestions, we need to analyze changes in Korea's trade patterns by conmoxdity group befure and after NAYHA. 'This way, we can see whether any specific categories of goods have been more affected by NAFTA, or whether all categories of groods were affecred uniformly and equally. Assuming that the share of Kurcan expores in the Ij.S. and ROW markets in 1991 would remain constant in the 1990), we priject the Kurean exports in these markets before and atter NAFTA and compare rhosn with artual Korcan cxports in those two markets. This is fone for cach 1-digit SITC industry group and for all groups together. In this way, we can also lonk inte any shifts in Korcan exports in the two markets (Table 5). 
Table 5. Shills in Share, Korfax fXports jo ThH L'S., 1991-1998

ITnit: U.S. billion;

\begin{tabular}{|c|c|c|c|c|c|c|c|}
\hline & $\begin{array}{l}\text { Iotal Lis. } \\
\text { impents from } \\
\text { the workd }\end{array}$ & 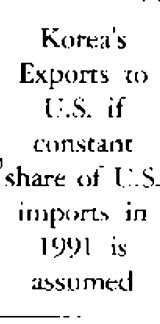 & $\begin{array}{l}\text { Changes due } \\
\text { to shifts in } \\
\text { actual list } \\
\text { imports } \\
\text { (itctuil-isssu } \\
\text { med! }\end{array}$ & $\begin{array}{l}\text { Total ROW's } \\
\text { imports from } \\
\text { the worle } \\
\end{array}$ & $\begin{array}{l}\text { Korea's } \\
\text { exports to } \\
\text { Row if } \\
\text { cusstant } \\
\text { shate of } \\
\text { Roty } \\
\text { imports in } \\
1996 \\
\text { assumed }\end{array}$ & $\begin{array}{l}\text { (hanges due } \\
\text { to sthifts in } \\
\text { actual Row Cl } \\
\text { imports } \\
\text { (actual-assu } \\
\text { med) }\end{array}$ & $\begin{array}{l}\text { Net } \\
\text { hanges due } \\
\text { (1) shifts in } \\
\text { Shate }\end{array}$ \\
\hline \multicolumn{8}{|c|}{ Total (includings all communditites) } \\
\hline (x)! & $5(k)+3$ & ls.6r & $0 .(1)$ & 36189.1 & 53.3 & 0.0 & 0.0 \\
\hline \{y)? & 552.6 & 20.2 & -2.1 & $3 \geq 35.8$ & 36.8 & $1 . ?$ & $-(0.4$ \\
\hline 19903 & $\ln 0.0$ & 19.9 & -3.8 & 3152.5 & 341 & 1.). ? & 5.9 \\
\hline 1904 & 6843 & $\therefore 5.2$ & $?$ & 3625.6 & 62.5 & 190 & 8.3 \\
\hline 1655 & 771.6 & 25.2 & $-4,0$ & $436 i 3$ & 75.2 & 3.5 .7 & $21 ?$ \\
\hline 1996 & $81 ; .8$ & 20). & -8.1 & 15589 & ?Xifi & 39.3 & $21 \ldots$ \\
\hline 1907 & $x(8) ?$ & $3>8$ & -11.3 & $173 ? 2$ & $S: Z$ & 32.5 & 21.6 \\
\hline $190 \times$ & 9) 4.6 & 34.5 & $-1 j .1$ & $3(x) 1.2$ & 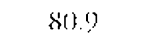 & 28.1 & 17.0 \\
\hline \multicolumn{8}{|c|}{ SITC 5 Chemicals ated related potedute, n.e.t. } \\
\hline 19i)1 & $25 \%$ & $0 . . ?$ & b. 0 & 281.8 & 2.) & 0.0 & iJ.ij \\
\hline $10 \times 12$ & $2 \times, 5$ & 0.3 & (jij & ii) $t(0$ & 3.2 & 1.0 & 1.0 \\
\hline $150 \%$ & 30.5 & 0.5 & 0.0 & $29 \times 0$ & $\therefore 1$ & 1.5 & 1.5 \\
\hline $150 \%$ & 35.5 & 0 & 00 & 355.0 & 3.7 & 2.3 & 2.2 \\
\hline :1) & $\cdot\{2.2$ & 0 & 0.0 & $43 t .5$ & $\div 5$ & í. & i. \\
\hline $14 x)$ & 46.6 & 0.5 & 0.1 & $t(1)$ & $\therefore 6$ & 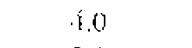 & 4.1 \\
\hline 1097 & 50.3 & ij. 5 & 0.1 & 457.2 & 4.8 & $5 ;$ & 5.4 \\
\hline 1048 & 56.4 & 0.5 & (b.) & 456.0 & 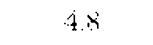 & 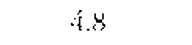 & (1.) \\
\hline \multicolumn{8}{|c|}{ 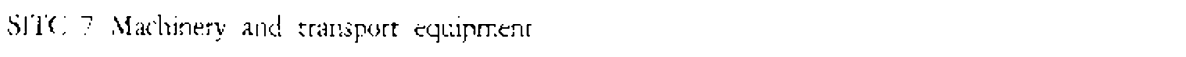 } \\
\hline$i j \times j$ & $21 \overline{3} \overline{3}$ & 8.9 & $(1,0)$ & (1)住. & $\therefore 1.1$ & (t.o & 0.0 \\
\hline $19 \% 12$ & 237.0 & 9.8 & $-(1) . ?$ & 1138.5 & 25.16 & 0.5 & $-(0, \therefore$ \\
\hline $10 \% 5$ & 265.6 & 11.9 & -0.9 & $\lfloor 121,0$ & 226 & . 13 & 3.4 \\
\hline 1)以保 & \$34.6 & 13.0 & $-(0.3$ & $1.25001)$ & 26.2 & 8.2 & $\because 1)$ \\
\hline |니 5 & .457 .9 & LA. & $? 0$ & 1571.8 & $j 1 . x$ & 17.2 & 19.7 \\
\hline 1996 & $36 \% 2$ & 15.2 & $0 . \dot{0}$ & $16 ; 6.1$ & .33 .5 & 19.3 & 18.9 \\
\hline $109 ?$ & 305.9 & 16.3 & $-2 \vdots$ & 1713.1 & 35.2 & 18.7 & 16.6 \\
\hline 1908 & 4.516 & 17.8 & $-3 . x$ & $1 ? 70.5$ & 3.5 .8 & !5. 1 & 11.6 \\
\hline
\end{tabular}

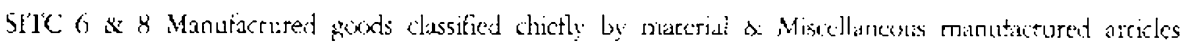

\begin{tabular}{|c|c|c|c|c|c|c|c|}
\hline 19) 1 & $14 ? 6$ & 9.2 & i). 0 & $81+5$ & 26 & 0.0 & i).(1) \\
\hline 1992 & $1(1 \geq 1)$ & 1). 1 & -1.2 & (9) 2 26 & 26.8 & 0.8 & -2.5 \\
\hline 1903 & 178.9 & 11.1 & -3.7 & 87 i.6 & 25.9 & 1.6 & -31 \\
\hline 193.4 & 2012.2 & 12.5 & -5.1 & 1021.5 & $3 y 7$ & -0.4 & -5.8 \\
\hline 1045 & 223.3 & 139 & $-? .3$ & 1236.6 & $\$ 6.1\}$ & -1.6 & -8.4 \\
\hline ]1) & $2 \div 28$ & 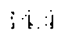 & -8.5 & 12.496 & $3(1,1$ & -3.1 & 11.6 \\
\hline $19 \% ?$ & 2500 & 15.5 & -4]$. & $12 \div 8.9$ & $3: 5$ & -2.8 & -13.9 \\
\hline 1908 & $286:$ & $1 \div .8$ & -10.1 & 1355.7 & 350 & 2.6 & 12.7 \\
\hline
\end{tabular}

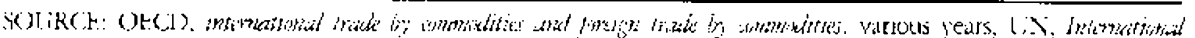

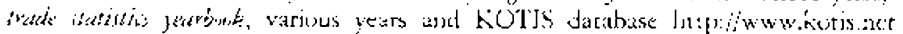

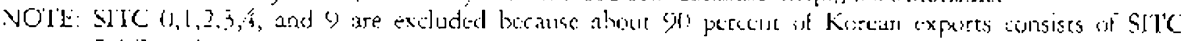
$5,6, ?$ and 8 is. 
Before 1991: Korcan cxports applated to lose their share in boch VAFTA and ROW rnarkets. Howcuer, since 19\%1, and especially after 1995, Kirtea concinued lowing its share in the NAFTA market but gatued in the ROW market. Moreover, ganns in the ROW more than offset losses in the NAFTA market. The net gains range from $\$ 17$ billion to $\$ 22$ billion fer year. This makes an interesting contrast with the findings of Kruegrer's (2000) aralysis in the case of Mexico. Krueger found that the share of Mexioun exports increased in the U.S. market, but lost in the ROW in the late 198()s and arly 1990s. I lowever, since the early 14y)s and especially after lygk, Mcxico's share not only increased in the l:.S., but also in the ROW' Kruegeres interpretation is that rather than VAFTA resuleing in the trade diversion from the ROW w Mexico, Mexico's trade liberalization at the snd of the 1980 s and the sharp peso devaluation in logy account for the sharp increases in lexican (xports ti) bxoly the [I.S. and ROW' markets since tarly 1990s.

Tathmg into accoune the findings or Mexico, a correct incerpretation should be that Kurca mas losing its relative effictency in both the U.S. and ROW by logen.

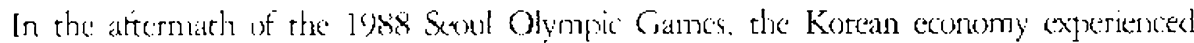
a high rate of inflation and the Korcine cisfency was orcrvaluad. Also. Chinais exports were making inroads in U.S. markers. replax ing Koccas traclitional cxports, especially in light industries such as extiles and apparel. Sinec 199), however, Korean cxports have been gaining international comperitiveress in the ROW, but trave uon been sufficient to cosngete with Mexican experts in the U.S. market. This is due mainly

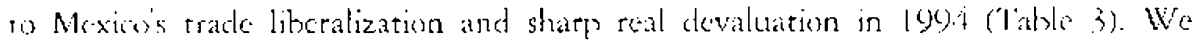
suspert that NAFTA must have lexped Mexico's exports increase it the U.S. market somewlat, but fundamentally, Korcan expurs' ctiticiency was not high enough to compcet with Mexico. This is the main reason why the share of Korean exports in LI.\$. markers comrinued dectining atrer NAFTA.

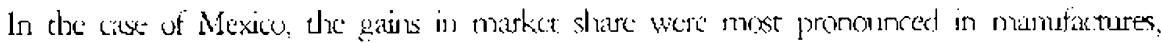
classiffed chiefly by materials. makhincry and tearsport ejuipment, and miscellaneous

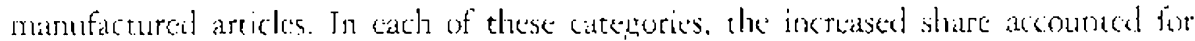
about lalf or more of the increment in Mcxion exports. Moreover, in each of chese categories, the increared Mexican share in trade with che rest of the worlst was almest as large as the increase in share of track with the I'S. (Kriger 2000 .

For Korea: gains in share have taken place mostly in chemicals and related products, as wcll as mothirien and tsansport eguipment. Especially in the later seroup. Korean

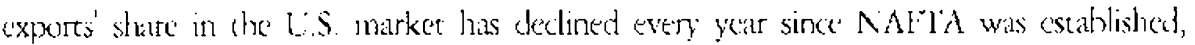
hut has increased in the ROWW marker. This indicates thate this group's efliciency was high coughth to sumpere in the ROW, but not in the U.S. (cospecinlly because of competition with Vexican grekels that has! increased efficiency not by the preferential

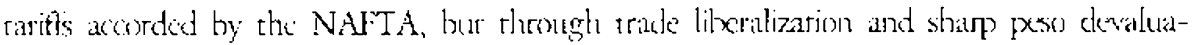
tives (Krugerer 2000$)$ ).

It is interesting ro note that in manufactured goods classified diedly by materials and miscellaneous mantitactured articles, Korea's share hats fallen wery year in both 
the U.S. and ROW markets. This mans that Korea's comparative efficiency in those goods has eroded in both markets. In other words, the decrease in the share of Korean exports to the If.S. market was caused more by the relative inctficiency or comparative disadvantane of some specific Korein exports, wather than the preferential tarifts acconded a NAFTA members across the board.

To substantiate this point, it wonkd be instructive to look more in-elepth at the extent to which each category of guods has been affected by the tariff reductions and ethen to compare its relative efficiency or comparative axlsantage in the incomational market. We examine changes in tarift rates and changes in the share of U.S. imports from Mexico and Korea for all 3-digit industries and for sclected industries in which Mexico gained market share by more than 10 percentage points between 199? and 1997-1998, following the similar analysis made by Krueger $(2000)$.

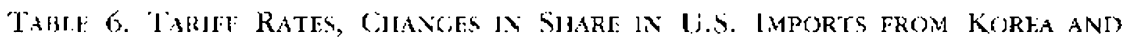
Mexico, $1992-1998$

\begin{tabular}{|c|c|c|c|c|c|c|c|c|c|}
\hline \multirow{3}{*}{$\begin{array}{l}\text { Commodity Category } \\
\text { stic Corle and Vane }\end{array}$} & \multicolumn{4}{|c|}{ U.S. Iariff Rates" } & \multicolumn{4}{|c|}{ Shares of C.S. Imports" } & \multirow{3}{*}{ Elasticity } \\
\hline & & & 19 & & 19 & 92 & 10 & 98 & \\
\hline & \multicolumn{4}{|c|}{ Korea Mexico Korea Mexico } & Korca & Mexic & Kurca & Mexics & \\
\hline 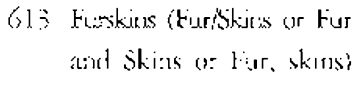 & 4 & 5 & 3 & 1 & 1.8 & 0.2 & () $s$ & 11.8 & 5.9 \\
\hline 846 Cluching atcessortes & 5 & $\check{2}$ & G & 1 & 9.1 & 0.9 & $\therefore$ S.t & 12.5 & -0.8 \\
\hline 782. Transpore roust vatudes & 6 & 3 & 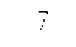 & 1 & 0.0 & 4.6 & १.१ & 32.6 & 6.1 \\
\hline GS2 Wowen comon fithrics & $i$ & i & i & । & $\{. . ?$ & 1.7 & 3.5 & 10.6 & 13.a. \\
\hline 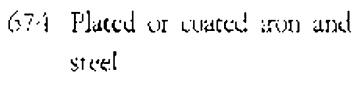 & ? & 3 & lij & 3 & 6.6 & 37 & $x .0$ & 18.3 & 16.6 \\
\hline $\begin{array}{l}\text { 672 Primaly iroan and stect } \\
\text { torms }\end{array}$ & $?$ & 6 & $s$ & 6 & $0 . \overline{7}$ & $\therefore 3$ & 1.6 & $20 . \hat{i}$ & 1.3 \\
\hline S:3 Meters and commers & i & 1 & $?$ & 1 & $0 .:$ & 12.5 & 0.1 & 63.5 & -24.7 \\
\hline 5i) busecticitses, tunglicides & $?$ & : & 7 & 0) & 0.5 & 2.3 & 0.3 & $\dot{x} . \bar{i}$ & 220 \\
\hline 62 Sigar contectimery & is & 2 & 6 & $?$ & 0.9 & 58 & i) 6 & 176 & 11, is, \\
\hline 266 Synchertix tilkers & 10 & 2 & $1: 2$ & 3 & $20):$ & 3.1 & 23.6 & $1 . \bar{i}$ & -2.9 \\
\hline 245 I.uel wasts & 28 & 1: & $\therefore 4$ & 5 & í.i1 & $2()$. & 0.1 & 18.6 & $10 . j$ \\
\hline 5.4 Waste of plastios & 12 & 2 & 15 & 5 & 0.1 & 4.5 & 0.7 & 19.4 & ก.a. \\
\hline $\begin{array}{l}\text { ?1] Electric power matiatery } \\
\text { ocher than gencraring }\end{array}$ & l & 0 & 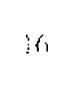 & 3 & i).:- & 4.8 & $? 0$ & 9.1 & $-(1)$. \\
\hline 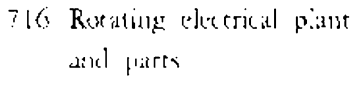 & $\mathbf{i}$ & ! & 3 & () & $? 0$ & 20.8 & 2.6 & 34.8 & -28.5 \\
\hline $7(1)$ IV receivers & 3 & 0 & 1 & (1) & 6.6 & is. 6 & 1.7 & ‥ & 21 \\
\hline Average all 3-dight industries & 4 & 2 & 3 & 1 & 3.1 & 6.5 & 2.6 & 10.2 & ณ1.4. \\
\hline
\end{tabular}

SOUJRE. al Krucger (200)i

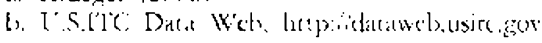


In 1992, the average tariff tates applicd to imports from Mexico were gencally less than the average tariff rates for comparable imports from Korea. For all 3-digit industries as a whole, the average tariff was $4 \%$ for imports from Korea, but only 2\%: for Mexico. This may sound strange under the CoITT rule of Most Favored Nittion (MFN) treatrnent. However, this was due to the U.S. trade prolicy fior the macuiliadora (kick-back) industries in Mexico, which were entitled to dury-free entry into the L'S. for those components that had been exported from the LS. to Mexico and then rexexported to the U.S. 'This is norhing but the rule of origin (ROO) set at $100 \%$ on parrs and macerials under a preferential trading arrangemene (PTA). Therefore, some imports from Mexico must have taken advantage of dhis rule. After $\mathrm{XAFT}$ i took effect, the average tariffs applied to imports from Mexico and Korea had the same difference of 2 percentage points, as before NAFI'A for the industries als a whole ('Tathle 6). And average tariff rates for all innpors from both Mexico and Korea were lowered by 1 percentage point between 1992 and 1997. Therefore, innpurts from Mexico as a whlle enjoyed avetage tatiff preference over imports from Korat ly 2 perentage points in 1997, ats in 1992. As a result, in 1997, no 3-digit industries in Mexico had a greater tariff preference than before by more than 2 percentage points, except tor transport road whicks (SITC: 782 ) and clectrical power machinery other than generaring equipment (SITC 711 ).

Despite the same degree of earff preferetere green for innerts from Mexico over Kurca befere and after NAFIA's estallishnent, Mexico's share of U.S. innpores increased by 3.7 percentage points, while Korea's share declined by 0.5 percentage points for

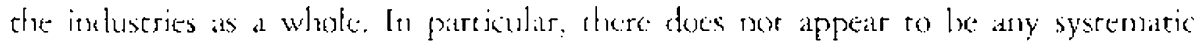
relationship between the changes in tariff rates and changes in market shares.

Among those 3-digit industries in which Mexico gained 10 percentage points of U.S. irnports, Mexicu's share of U.S. imports encreased more sharply in fur-skins $(613)$, cloching acessorics (\$46), transport road velicles (782), woven entron fabrics (652), and plated or conted iron/stecl $(674)$. For these industries, the gap in the average tarifft rates betweter Mexico and koreal dist not increase: unusually, cxictpr for transpert roid velicles (782).

In those industrics for which the gap in average tariff rates for Mexico and Korea increased by more than that for the whole industries, i.e. transport read vehicles (fiom $;$ to 6 percentage pxints) and electric power machinery (from 1 to 13 percentage poines). Mexico's share of US. imports did not change erenly. On the one land, in trinspert road vehicles (782), Mexico's shase increased sharply (from $4.6 \%$ to $32.6 \%$ )

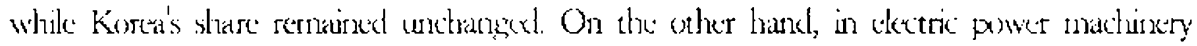

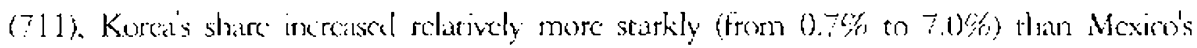
share (from 4.8\% to 9.1\%). Mexico must have had a comparattive advantage in dhe roanspore road velicle industry, and Korea must have had a comparative advantage in the electrical power industry

Therefore, for all 15 industries, estimation was made on the elasticity of the changes in the difference lectween Mexien and Korea's shate of U.S. imports with respect 
to the changes in tariff preferences accorded to Mexico wer Korca before and after NAFTA was established (Table (i). For seven industries, the elasticity was pusitive and greater than 1. Howerer, the elasticity was negative or infinity in cight industries. This means that in these ejght inclustries, the Mexican share of L.S. imports either cleclined sharply as the tariff preference materin rose or increased even though there was no change in tariff preferences berween the rwo countrics betore and after NAFTA. For increases in Mexico's share of L.S. imports, therefore, credic should be given not to Mexico's tariff advantage accorded by NAFTA, bur to the improved efficiency in these Mexican industrics, which must have rosuled from the trade liberalization and structural adjustment at the end of the 1980s and the sharp real devaluation in lyy4. Conversely, it would also he true that the decline in Kuscis share of L.S. imports was nut due mainly tu Korea's tariff disadvantage accorded by NAFTA, but te ehe incfficiency of these Korcan industrics. There was no difference in the average tariff preference given to Mcxico vis-à-yis Korea before and after NAFTA acruss all manutacturingr industries.

\section{REGIONAL ORIENTATION INIDEX}

The above analysis has limications in two respects. First, it has been made on the basis of two discrete observations in 1992 and [947-98. Second, the analysis focuses on L:S. imports and loes not take into account any clanges in the ROW matrket. Thereture, a further analysis is made on the basis of continuous ohservacions

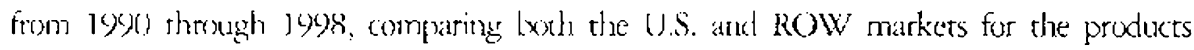
of the same 3-digit industries. For this purposc, the traditumal reginal orientarion index is moditied. The modified regrional orientation index is defined as follows:

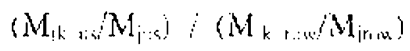

where $M_{1 k_{-} \text {is }}$ and $M_{i k_{-} r w w}$ are values of Korean product, i, imported by the U.S. and ROW, respectively, and $M_{\ldots}$, and $M_{\text {axis }}$ are total values of all countrics' product $;$ imported by the L.S. and ROW' The index indicates the proportion of Korean product $j$ co the total value of all conntries' produce $j$ imported by the L.S., relative to the propertion of Korears product $j$ eo the total value of all countrics' product $j$ imported by the ROW?. If the index value is unity, the Korcan product $j$ is equally connperitive in both the U.S. and ROW markets.

When the nuditied regional orienrarion indices are computed for carde of the 3-digit inchustries over the period 1990-1998, ebey declined before and after NAlTA for most industries. This indicates that Korean products were beconoing less efficiene in the U.S. mirker compared to the ROW market, especially atter NAtIA 'Table 7. The exceptions were dothing accossorics (8/6), primary iron and steet forms (67)), and synthetic filxers (266), for which the modified regional oricntation index was 
either stathle or increased over the periox. These industries have a comparative adyantalye in the U.S. market despite the tariff preference and release of non-quancitative harriers accorded to NAl'A members. In sum, before and after NAFTA, Korean exporss' share of the UIS import marker did not change uniformly and cqually among all industries, but changed according to their international competitiveness or comparative advantage, irrespective of the degree of their tariff disadvantage vis-à-vis Mexican exports

TAHLE 7. RUGGNAI. ORIENIATION INDFX, 1990-1998

\begin{tabular}{|c|c|c|c|c|c|c|c|c|c|c|c|c|}
\hline SITC & 873 & 846 & 782 & 761 & 716 & 711 & 674 & 672 & 652 & 613 & 591 & 266 \\
\hline 1900 & 00 & $\langle j . ?$ & 0.0 & 0.4 & $? 3$ & $2 \ldots ?$ & 0.3 & 0.0 & 1.2 & (i.) & 1.( ) & $0 . ?$ \\
\hline 1901 & 0.0 & 0.7 & $0.0)$ & 1.0 & 30 & 6.1 & 0.5 & (3.6) & 1.1 & 1.5 & $1.6)$ & 11.8 \\
\hline (1)y & 19.0 & 0.8 & (3.) & i). & 2.4 & 0.3 & 0.4 & $0.0)$ & 1.2 & 0.0 & 0.9 & 1.1 \\
\hline 1993 & il. (i & $\therefore 1$ & $(1,8)$ & 0.3 & 2.1 & 6.6 & 0.1 & 0.0 & 12 & 0.0 & 0.9 & 1.0 \\
\hline$(y) i$ & 11.01 & $\therefore$ & $0.0 \mathrm{j}$ & 0.2 & 2.2 & 110 & iJ. 1 & $0.0)$ & 11.9 & $(1.0)$ & 0.4 & 0.8 \\
\hline (13) & 01.0 & (j.9) & (j). (j & (1.2 & 1.9 & (1). & 0.1 & 0.6 & 10 & i). ! & 0.3 & 0.8 \\
\hline $119 i)(1$ & 0,01 & 3.1 & (1). 0 & (1. 2 & 1.6 & 1).1 & 0.1 & (0.1 1 & $0 . s^{\prime}$ & (I. (i & 0.3 & i3.8 \\
\hline$[.5 y ?$ & 0.0 & 1.6 & (1.) & (b) & 1.8 & 1. . . & (0. 1 & 0.2 & 0.? & (J.: & 0.1 & 0.6 \\
\hline 154 & (1).1] & 1.5 & 0.0 & 0.5 & $\therefore 0$ & 13.3 & (1). : & (1). 1 & 0.9 & 00 & 0.6 & 0.17 \\
\hline
\end{tabular}

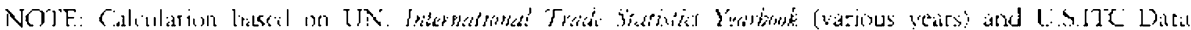

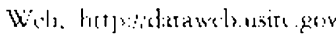

\section{GRAVITY MODEL ANALYSIS}

Then why has Korean exports share of the NAFTA market declined even before the restrictive rules of origin, coupled with large margins of prefercntial tarifts, were applicel anomg NAITA members? What explains the behavion of Korean exports in the ITS. and ROW markets betore and atter NAFIA? lo answer these questions. n'e now turn to an analysis using a form of gravity equations. Although the theoretical foumdiations for these retations are less than rigorous, these molels perform well empirically and can shed useful light on the trading patterns among countrics (Frankel 1998).

Our tirst attempt is to sce if NAFTA has significantly affected Korean export perfurmance before and after it teok effect. This is done using three durmmy variables: (1) any special factors in every 2-ycars beforiafter NAFIA; (2) NAFIA membership; and (3) the trend (the number of years past) since 1987, de fictor start of the NAFIA.

Other inclepenterit variahles include the distance between Korca and its trading partners, as well as the population and GIDP of Korea and its trading parner countrics, usually incluedel in a gravity model. This moxtel is buile on the hypothesis that a country"s trade performance is positively dependent on the size of trade partnets or potential sales in the partner countries, and negatively related to the distance between the trading partners. In addition, our model uses a remoteness variable to 
take into account the fact that some crading partucers are further away from most trading partncrs, following the study by Kruger (1999). Two restote countrics might be expected to trade more with each orher than with many relatively proximatc trading partners.

$\Lambda$ pooled time-series and cross-section regression was cstinated with the following form:

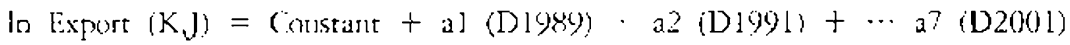

$$
\begin{aligned}
& +b l \ln (G D P-K)+b 2 \ln (G D P \cdot J) \div(1 \ln (G D P p-K)
\end{aligned}
$$

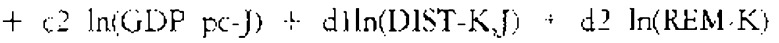

$$
\begin{aligned}
& +d ; \ln (\mathrm{RLN}-\mathrm{J}) \text { - el (NAFIA-J) + (2) (TRENID-NAFTA-J) }
\end{aligned}
$$

where $\mathrm{K}$ and $\mathrm{J}$ denote Korea and its importing partncrs, respectively; D)1989, Dl901, ets. are year dummies; GDP-K and GDP-J and GDPp-K and GDPPC-J are GDPs and GIDP per capira of Korea and its importing partners, respectively converted into constant 1990 L.S. dollars); DIST is the distance betwecn Kurca and its trading partners: RENA-K and REM-J are the weighted (by GIDP) averages of the distance from Korea and its trading partners, respectively. The dummy rariable NAFTA-J is 1 if a Korca's rading parterer is a member of the NAFTA and IKLND-NALIA-J is the number of years elapsed since 1987 , the de factor start year of NAFTA.

The source of rade dara was the Workd Bank's World Integraced Tradesolution (WITS), based un UN COMTRADE data. GDP and population were bised on the World Bank's World Development Indicators. For distances, consult hetp//hwmindo. comidistance. These are 55 countries included in the sample, which are comparatle to the 61 countries used by Irankel (1997). Each country has beern ubserved seven rimes on averige for a perind of 15 years (1980-2001).

Lstimation of the coluation was made on the hasis of the random effect model (error-components model) of the nuxinum likelihood regression (Kmenta 1971).

Results of the regression andysis are as follows (Table 8). Natural log likelihood and I.R (hi sguare staristics are significantly high. "The coefficients of year dummy varballes are positeve and stattistically significant at the 1 or 5 pereent level berween 1989 and 2001 . It is interesting to note that overall Korcan cxports were positively affeced in those ycars atecr NAFTA's inception by somc factors not considered in this cefuation. The coxficient of rading partocers' (iDP is large, positive, and statistically significane, as is usual in gravity equation analyses; the coefficiont of the per capita GDP, however; is small and non-significant:

Contray to the comnon resules of gravity analyses, the distance dummy is relacively large and positive, but not significant. This is contrary to cur expectations, since Korean exports to neighboring Asian countrics ranged betwecen 35 and 50 percent during the period under review. "This unexpected sign of the coefficient may be considered together with the negative, larese, and significant coefficient of the remoteness variable. Korean exports cluring this perixt have heen negatively affecred by trade with relacively remote countries to a substantial slegree, since they trade nore among themselves. 
The unexpected sign of the distance variable may be duc to the fact that Korean overseas direct investonent (ODI) ruse sharply since NAFTA's inception, except during the 1997 Asian Financial Crisis (Figure I). Perhaps Korean exporters raised the level of ODI in the NAFIA area to compensate for any negative effects of NALTA on their exports and took advantage of the rule of origin and the proximity of $N A F T A$ member countries and lattin America. Korean ODJ firms may have increased imports from Kurea to setl their products in neightoring NAFTA and Jarin American countries. Conscquenely, Korcan ODI may have positively affected Korcan cxpores. However, this hypothesis could not be empiricatly cesed as data are not avaliable on the expurts of those Kurcitn ODI firms lexated in the NAFTA area. A furcher study to account For Korean trade paterns sime $M A F T A$ would recule an analysis of the import and cxpore performance of Kurean ODI firms locited in the NAF"lA arca, especially' in Mexico, where labor costs are less expersive than in Kurca.

The coeflicient of NAl'A memlership, our main interes in this analysis, is negative and relacively large, hut staristically not significant. Likewise, the coetficient of TRENL-NAFTA is small and pusitive, but not significant. "Therefore, we cannot state that variations in rade with NAFIN memher countries and the length of their NAFTA membership affected Kurean exports negatively.

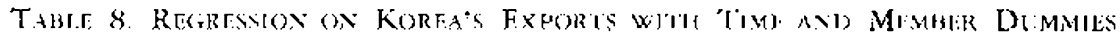

\begin{tabular}{|c|c|c|c|}
\hline & Coufficient & standard error & $\Gamma>l>l$ \\
\hline Cuns & 11.33 & 301 & (ii) \\
\hline Dosy & 21 & $\left(u^{\prime}\right)=$ & .02 \\
\hline 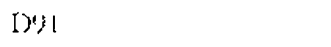 & $\therefore 2$ & (J)? & (1)io \\
\hline 1.93 & $\dot{x} . ?$ &.$\left.i j^{\prime}\right\rangle ?$ & .00 \\
\hline 095 & 1.20 & .091 & .00 \\
\hline 1): & 1.28 & (以) & .00 \\
\hline$[x)$ & $1 . \leqslant 1$ &.$j i k j$ & .00 \\
\hline 1$)=1$ & 1.20 &.$(1) 8$ & (u) \\
\hline \multicolumn{4}{|l|}{ L:I GLPk istopondi" } \\
\hline I.a $\mathrm{CiDP}_{j}$ & 73 & $(0):$ & .0 \\
\hline \multicolumn{4}{|l|}{ Lo GDPpek "dropped" } \\
\hline$L_{u}(; 1) P_{p} x_{1}$ & $.(\})$ & .101 & $81)$ \\
\hline In IXISIj & .97 & sis & is \\
\hline Tn IESMOT: & -1.26 & ¿ & i) $\mathrm{s}$ \\
\hline \multicolumn{4}{|l|}{ Tn REMOTj Groppes: } \\
\hline NAETA & .52 & 360 & .16 \\
\hline THEND NAFTA & $(;-7$ & 125 & .596 \\
\hline l.n likeliturin? & \multicolumn{3}{|c|}{$-380.51 .21$} \\
\hline LR Clii sul $(1 ;)$ & \multicolumn{3}{|c|}{663.51} \\
\hline $19 i$ & \multicolumn{3}{|c|}{133} \\
\hline
\end{tabular}

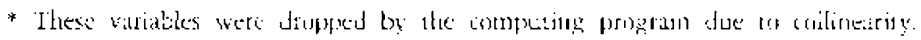




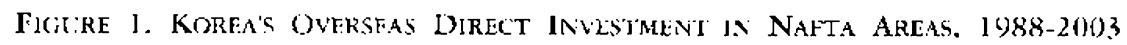

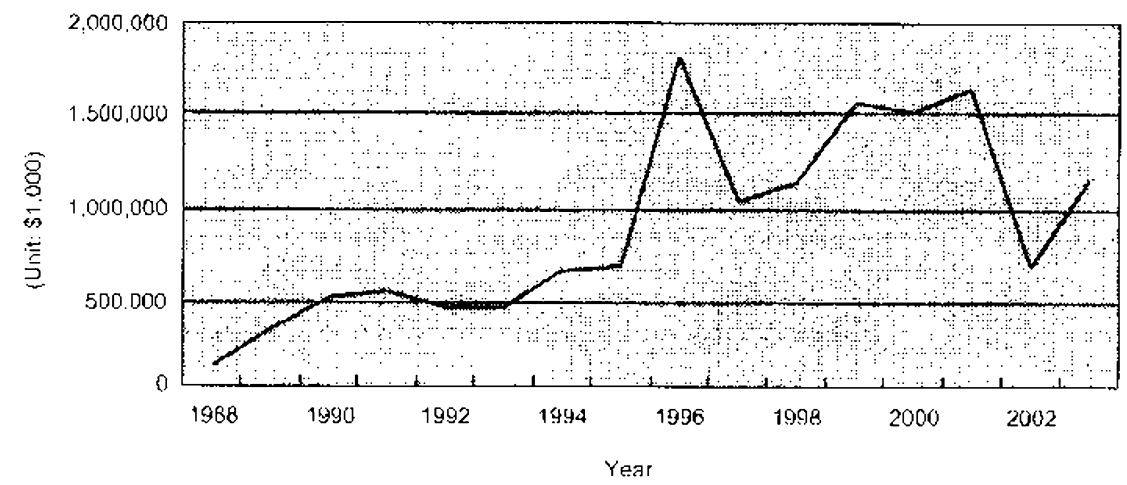

SOTRCL: www'kurencxingo.he

\section{CONCLIISIONS AND POLICY IMPI.ICATIONS}

Even though we have focused on the static analysis of the trade effects of $\mathrm{NAF} \Lambda$, it is nut casy to isolate thase cffects from other economic polisics and events. During the period under study, many economic events took place that must have affected trakje of NAFTA member countries, in particulas Mexico, and their trading partners including Korea.

Mexico undertook drastic reform measures ro liberalize trade and experienced a 5harp real devaluation of its currency on the order of $50 \%$ in 1994. Irade litweralization brought down the average carifi rate from mese than $40 \%$ in 1987 to about $13 \%$ in 1989, and to 10\% by early 1990s. Therefore, accions towards frec trade preceded NAFlA in Mexicu. Even from 1989), the relatively low tariffs (escimated at 6\%) on maguiladora impores and the implementation of the Canada-L:S. Frce lirade Agrecment (C.USTA) moant that imports into rhe U.S. From Canada and Mexico alrady enjoyed preferential treatmenc. Moresver, the magnitude of curlies tariff recluctions was mucl more drastic than those mate under VAFTA, which were on rhe order of $1.4-3.3$ petcentinge points (Iat)le 9). Tariff teduction under the NAFTA did not ocar in one stut, but has been contmuing over ten or 15 years, depending on the serwor. In alddition, after the "tequila crisis" of late 1994, the Mexican government imposed a surcharge on all imports entering Mexico, except those from NAFiA member countries. All these and other facturs. together with NAFTA, muse have affected Mcxican tracle pattensis.

Likewise, the Kutean zovernment, in preparation for joining the OECD in 1995 , carried out major crade liberalization and the oprening of capital martets in the early 1990s. These policies have been accentuated after the Asian crisis in 1997 despite negative or slow economic growth rates.

Undoubredly, all these events and policics affecred trade between NAFIA members 
and their trading parners inchuding Korca. Thus it is difficult to discern the efferts of NAFTA on Korean trade and investment, let alone measute the magnitude of the net effects. Naturally, we will have to assess the cffects of NAFlA, together with those of severisl economic events and policies.

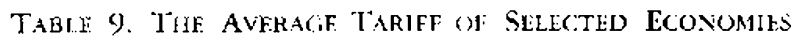

(L) lait: pretert!

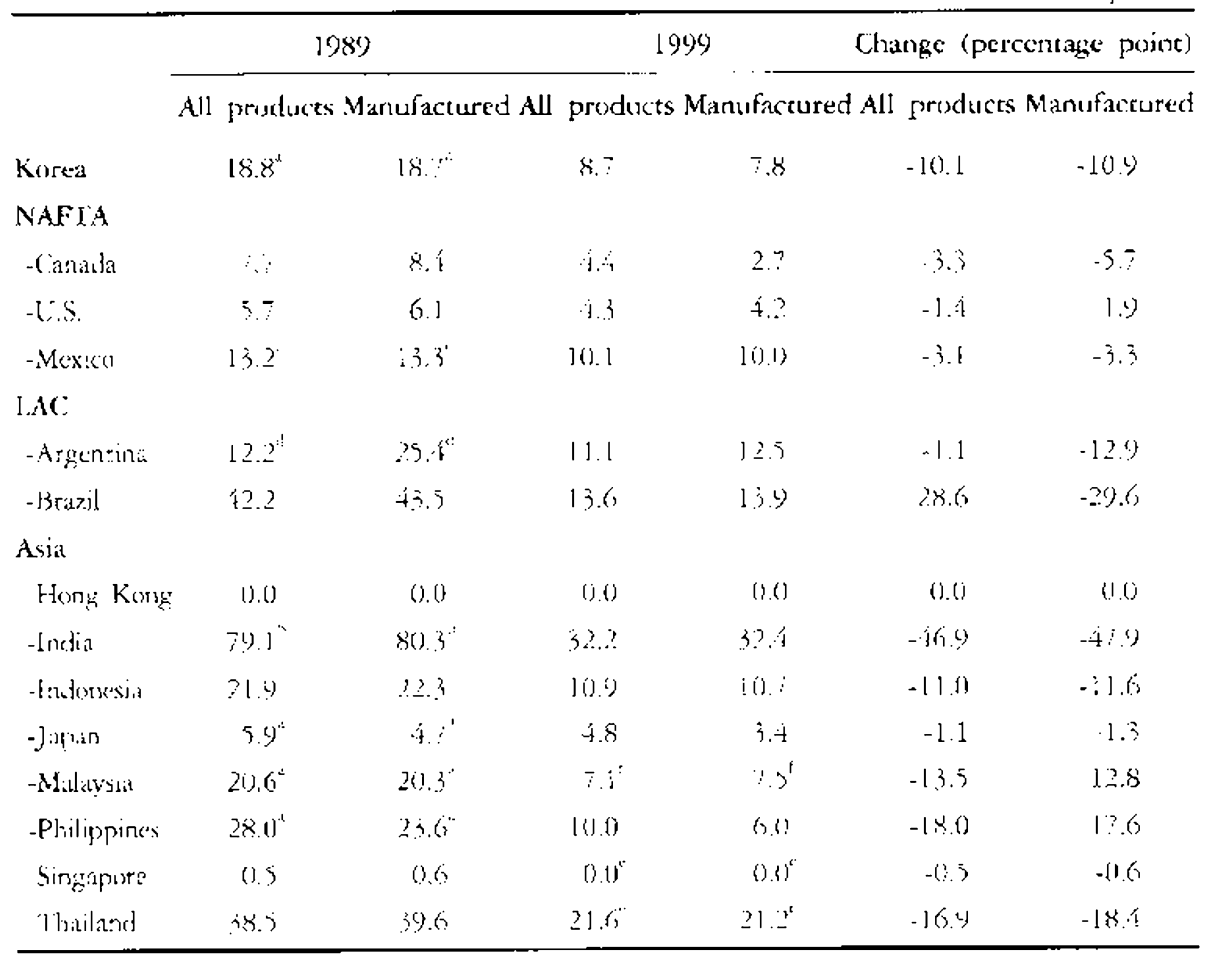

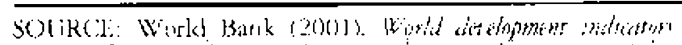

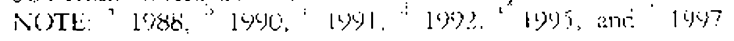

Broadly speaking. Korean exports share of the NAFTA market has declined atter XAFTA was formed. Simce NAFTA, there may tave been some trade diversion from Koreia to XAF'A nember cuuntrics, particularly Mexico. However, this was a continuation of the trend observed from the late 1980). Moreover, Korean exports' share of the ROW market has risen, compersiting for the losses in the share of traxk in the NAFTA market. $\Lambda$ s the regression analysis shows, Korean export values are positively associated with the post-NAFTA eat (1993-1999) at a significant level, and are negatively associated with NAFIA membership, hut nut significant.

The value of Korcan exports in the RoW' bas increased much more sharply atter NAFTA. Koreard exports to the VATTA market also reversed the dectining trend and have risen moxterately since NAFlA (Táble 1). There may bave been sums trade diversion after $X A F M A$ from Korea to NAFTA menber countrics. Hewever, trade 
creation in both the NAFTA and ROW markets has more than offset any possible diversion effect in the NAFTA market. Hence, NAF'A appears to have had some overall net positive effects on Kurean trade. The discrininatory protection of NAFTA, coupled with the strengthened effeciency of NAF'A products, must have provided impetus for Korean exporters to improve their products for the NAFTA market and may have resuforced the Korean exporcers' urge to expand their role in the ROW market.

'l'his study provides some lessons in anciciparion of the FTA $\Lambda$ and orther PTAs. Finst, a PTA such as the VAFTA (an serve as a buikling block toward trale liberalization on a global scale. As part of the preparation for NAFTA, member countries had caken tratc liberalization measures even before the formal PlA agreenent became effective. Sonne of those measures were more significant for tracte promotion than the preierence given under the PTA itself, and countries outside the I'TA also drew benefits from these measures.

Second, even if the North American preferential trade arrangement had any negative effects on the share and value of a nom-member country's exports, they werc casily offset by the impart of other macrocenomic policy alfustments. In Korea, trade liberalization and other structural adjustment programs, such as flexible foreign exchange policies hefore and afcer NAFTA, sem to have more than offset effects on the value of Korean exports destined to the PTA markets, including Mexico. 'Iherefore; a macroconomic policy adjusement would be more cffective than a PrA in promoting exports.

Third, the trade creationidiversion effects of a P'A are nut in proportion to the margin of tariff preference. Increases in the exports of an industry, where the margin of cariff preference was greater, were not uniformly greater than in wher industries. Exports of an inclustry where the margin of tariff preference was greater than in other industries did not actually increase much, while in another industry, exports increased more sharply. Given the limited magnitude of the prefercntial cariffs, other factors affected tradc: more, and therchy offset preferential tariff effects.

Fourth, when the margin of taritf preference is relatively small, as in the case of NAFIA, trade creation effects of a PTA have becin relatively limited. A more important factor for increasing trade share and trade creation is the international competitiveness of a product. Both PTA member and non-member countries should examine those products in which they have a true compasative alvantage and focus on hon to improve the competitiveness of those products in PIA and ROW narkets. Advancement of technology and accumulation of human capital involved in the production of a conmodity would generatc preater returns than woukd margins of tariff preference. 


\section{REFERENCES}

Anderson, Kym. 1983. Prospects for Trade Growth ameng Pacific Basin Countries. Developing Ecommizes 21 (December): $376-85$.

Arndt, Sycn and Alex Huemer. 2001 and 2002. Norch American Trade Afeer NAFTA: Part I, Part II, and Part III. Clakmmnt Policy Brief. Issues No. 01-(01, 01-()2, and 02-0)

l3ergsten. (.. Fred. 1996. Glohalizing Free Trade. Foreign Affairs 75: 105-20.

Bhagwati, Jagdish. 1991. The Wrold Thaling Sjotem at Rink. London: Harrester Wheatsheat.

Burfisher, Mary, Sherman Robinsun, and Karen Thierfelder. 2001. The impact of NAFTA on the United States, Jounal of Eumomir Perspetives 15: 125-44.

Drysdale, Pecer, and Ross (rarnaut. 1982. Trade Intensiries and the Analysis of Bilaterial

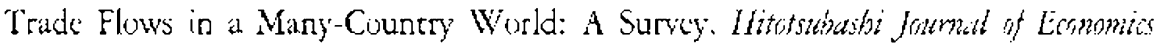
2(2): $62-81$.

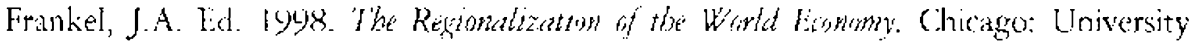
of Chicago Press.

Fukao, Kyoji, Toshihiro Okubo, and Robert Stern. 20033. An Fonometric Analysis of Trade Biversion under NAFTA. School of Public Policy, University of Michigan, Discussion Paper No. 791, Ano Artor.

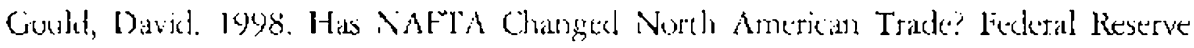
Bank of Dallas. Economil Ravar. Fim Qutater: 12-23.

James, Willian E. and Masaru Limomoto. 2000. NAFTA Trade with Ease Asia: Rules of Origin and Market Access in Textiles, Apparel, Forweat and Flectrical Machinery. ASEAN Eommic Bullum $17(3)$ (December): 293-311.

Karemara, David and Kalu Ojah. 1998. An Industrial Analysis of Trade Creation

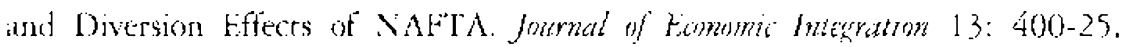

Kojina, Kiyoshi. 196\%. The Pateern of Trade anong Advanced Countrics. Hitntsubushi

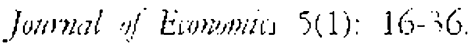

Kinenta, Jan. 19:1. Elements of temmetrics. New York: Macmillan Co.

Krcinin, Mordectai and Nictact Plummer. 1998. Ex Post Lstimates of the Luropean Single Market Programene on the Expons of Developitig Countries. ASEAN Eximumic Bulletin 15(21): 206-1.1.

Knugger, Anne, 2000. NAFIA's Effects: A Preliminary Asscssment. The World fiomm $23(6)$ (June): $761-76$.

199). larade Creation and 'lrade Diversion under NAFl'A. National Bureau of Lconumic Research, Working Papes 7 (1) (December).

Sloaga, Isidto and Alan Winters. 2(00). Reginnalism in the Ninecies: What Fffect

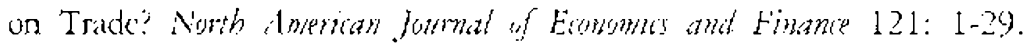


Viner, J. 1950. The Castoms linion Isske. New York: Carnegie Endowment.

Wall, Howard 2002. Has Japan Been Left Out in the Cold by Regional Integration? Foderal Reserve Bank of St. louis. Retitew 84: 25-36.

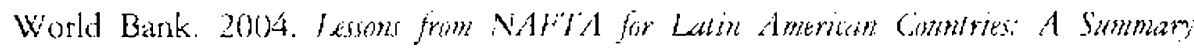
1) Revetwh linding. Washington, DC..: The World Bank.

Ycats, Nexander J. 1998. Docs Mercosur's Trade Performance Ratise Concerns about the Effects of Regrional Trude Arangements? The World Bank Lomonic Reriew 12 (1): $1-28$. 